\title{
リターナブルびんの内圧力負荷下における耐熱衝撃強度特性
}

\author{
横倉修一 \\ （麒麟麦酒（株）富田製震工場）
}

\begin{abstract}
内圧力を負荷した状態下でのガラスびんの熱衝撃強度特性を評価する目的で, 一様深さで軸方向 に連続的なクラック(Straight-front crack) 外表面に含むガラス円筒を対象に破壊力学的な解析を 行った.

まず円筒のガラス層に発生する熱応力を計算し，Bueckner の Weight Function を用いて，熱衝 撃破壊について表面傷深さと熱衝撃量の関係を検討した。なお限界応力拡大係数は Mecholskyに よる值を用いた。

このガラス円筒に関する理論的解析結果を半だ円形状 (Semi-elliptical crack) のクラックが発 生していると考えられるガラスびんに適用したところ，熱衝撃破壊に関する実測値は破壊力学的に 導き出された理論值とよく一致することが分った.

(1984 年 12 月 4 日受付)
\end{abstract}

\section{Thermal Shock Fracture Resistance of Returnable Glass Bottles Subjected to Internal Pressure}

\author{
Shuichi YOKOKURA \\ (Tonda Bottle Manufacturing Plant of Kirin Brewery Co., Ltd.)
}

\begin{abstract}
The thermal shock fracture resistance of reused cylindrical glass bottles subjected to hydraulic internal pressure was measured by quenching at outer surfaces. Next, on the basis of a linear fracture mechanics, fracture toughness of a glass cylinder with straight-front crack at its outer surface, under both thermal shock and internal pressure was theoretically calculated using Bueckner's solution (Weight Function). Further, the theory was extended to reused glass bottles with semi-elliptical cracks at their outer surface. As a result, the experimental results on the glass bottles coincided well with those of the theoretical ones of glass cylinders.
\end{abstract}

[Received December 4, 1984]

Key-words : Glass, Bottle, Fracture, Thermal shock, Internal pressure, Fracture mechanics

\section{1. 緒言}

ガラスびんは充てん工場において洗净，熱殺菌等の工 程で急冷による熱衝撃を受けるが，この熱衝撃に対する 強度, すなわち耐熱衝撃強度は従来から重要な強度特性 の一つとされている(1)4).

ところでビール，サイダーなどの炭酸飲料用びんにお いては, 内容液を充てんした後の熱殺菌工程で炭酸ガス によるかなり高いびん内圧力（最高 5 6 気圧程度）の 上昇が認められ，その状態下で急冷による熱衝撃がびん 外表面に加わる。この工程でのびんの破損を業界では一 般に“パストル破損”之呼んでおり，びんの品質を評価 するうえで重要な強度特性の一つに挙げている ${ }^{51,61}$.
このように内圧力負荷状態下で，びん外表面に熱衝撃 が加わった場合の強度（本報文では仮に “耐熱圧強度” と呼ぶことにする）については，びんの実用的な強度を 論ずるうえでかなり重要（例えば，炭酸飲料びんの熱殺 菌工程における急温, 急冷の温度プログラムの設定等) であるにもかかわらず，こ㧈までに著者の報告以外には

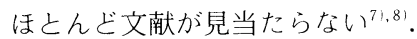

そこで本研究においては市場で繰り返し使用され，表 面傷が多数発生しているリターナブルびん（回収，再使 用可能)を対象として，あらかじめ所定の内圧力 (水圧) を負荷した状態で，急冷による非定常熱応力をびん外表 面に加えた場合の強度特性について検討し, 破壊力学的 
な考察を加えた。

\section{2. 実験方法}

\section{1 試料びんの概要}

びん形状としては我が国で広く使用されている円形の リターナブルびんの 1 種類を選んだ。試料びんはソー ダ・石灰ガラスであり，その化学組成は表 1 に示すとお りである. 試料びんの諸元は以下のとおりである. 重量 $350 \mathrm{~g}$, 内容量 $211 \mathrm{ml}$, 胴径 $57 \mathrm{~mm}$, 高さ $203 \mathrm{~mm}$.

試料びんは強度のばらつきが比較的小さい, 使用年数 5〜7 年のものを，市場より無作為にサンプリングして 選んだ。なおこの試料びんは円筒下部（底より高さ約 $15 \mathrm{~mm}$ ) 及び円筒上部（底より高さ約 $78 \mathrm{~mm}$ ) に表面傷 が集中しており，これらの位置は熱衝撃破壊試験におい て，破壊起点が集中する位置に対応しているが，その位 置でのガラス肉厚はいずれも等しく, 約 $5 \mathrm{~mm}$ であった (図 1 参照).

\section{2 びん強度試験法の概要}

\subsection{1 耐内圧力試験}

試料びんに内圧力（水圧）を加えて破壊させる試験装 置(アメリカン・グラスリサーチ社製, インクレメント ・ プレッシャーテスター，1200-Dual Head Type) を用い て,びん破壊時の内圧力を 1 分間持続の耐内圧力強度(所 定の内圧力を 1 分間持続させて破壊に至る強度）として 表示した ${ }^{9\} \sim 12\}}$.

\subsection{2 内圧力及び熱衝撃を同時に負荷する破壊試験} 試料びんに水を満量充てんした後，びん口部にナイロ ン製の耐圧導管を取り付け，それにプランジャー・ポン

Table 1. Chemical composition of a test bottle.

\begin{tabular}{lccccccccc}
\hline $\mathrm{SiO}_{2}$ & $\mathrm{Al}_{2} \mathrm{O}_{3}$ & $\mathrm{~K}_{2} \mathrm{O}$ & $\mathrm{Na}_{2} \mathrm{O}$ & $\mathrm{CaO}$ & $\mathrm{MgO}$ & $\mathrm{BaO}$ & $\mathrm{Fe}_{2} \mathrm{O}_{3}$ & $\mathrm{TiO}_{2}$ & $\mathrm{SO}_{3}$ \\
\hline 70.4 & 2.0 & 1.2 & 14.7 & 9.6 & 1.7 & 0.06 & 0.05 & 0.07 & 0.2 \\
\hline Note: Weight percent.
\end{tabular}

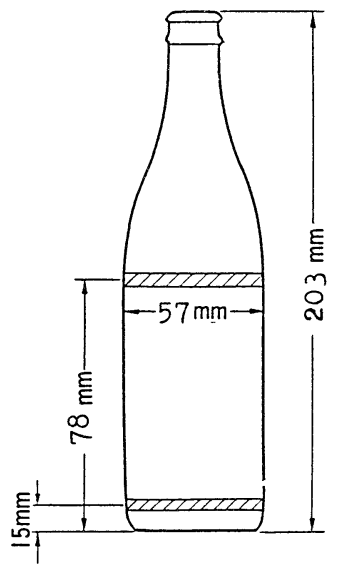

Fig. 1. Schematic illustration of a test bottle. Hatched parts indicate areas heavily abraded by repeated usage.

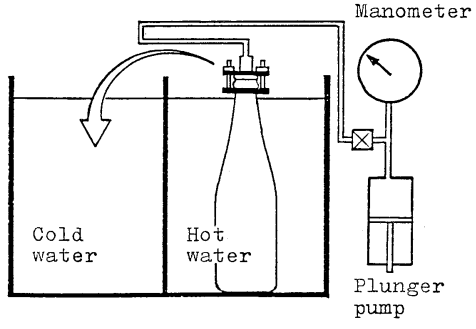

Fig. 2. Schematic diagram of an internal pressure/ thermal shock test procedure.

プを連結した状態でびんを温水槽に $1 \mathrm{~h}$ 浸漬した後, プ ランジャー・ポンプの稼動により耐圧導管から加圧水を 送り込み，びんの所定の内圧力を加えて $30 \mathrm{~s}$ 経過した 後, 冷水槽 $\left(10^{\circ} \mathrm{C}\right.$ 一定) へ移動させて，びん外表面に 熱衝撃を与えた。この操作を試料びんが全数破壊するま で温水槽の水温を $3^{\circ} \mathrm{C}$ 間隔で段階的に昇温させていく プログレッシブ・テスト法を採用し，びん破壊時の内圧 力及び温度差（熱衝撃量の尺度としての温度差）を各試 料びんについて測定した (図 2 参照)。なおびん内圧力 の調整は接点圧力計を用い, 電磁弁による自動制御方式 をとった。

\subsection{3 破壊起点における表面傷深さの測定方法}

この試料びんでは熱衝撃によるびんの破壊起点が加傷 領域（外表面）に集中しているため，その位置をダイア モンド・カッターを用いて輪切り状に厚さ $10 \mathrm{~mm}$ 程度 に切り出し，切断面をカーボランダム（粒度は最終的に 1000 メッシュ）で研磨し，切断面からの光の乱反射を 防ぎ, 輪切り片をそれと屈折率が同程度の浸液(アニソー ルあるいはクロル・ベンゼン）に浸漬した状態で，実体 顕微鏡により輪切り片の外端部（外表面に対応）を観察 し, 表面傷深さを測定した ${ }^{13)}$.

\section{3. 実験結果}

\section{1 耐熱圧強度}

試料びんにあらかじめ内圧力をそれぞれ0 (大気圧), 3，6，9，12，15 及び $18 \mathrm{~kg} \cdot \mathrm{cm}^{-2}$ 負荷した条件下で急冷 による熱衝撃実験を行った。その結果を図 3 に示す．図 3 の (内圧力-熱衝撃) 関係のグラフ群から累積破壊率 $50 \%$ における内圧力と熱衝撃値 (温度差) の関係をみ ると，図4 から明らかなように両者には直線関係が認め られた。

\section{2 耐内压力強度}

試料びんの 1 分間持続酎内圧力強度の測定結果を図 5 に示す。図 5 から明らかなように $\bar{X}=36.4 \mathrm{~kg} \cdot \mathrm{cm}^{-2}$ が 得られた。また内圧力破壊による破壊起点はびん円筒部 (底加高さ約 $78 \mathrm{~mm}$ の位置) の外表面（加傷領域） に集中していた. 


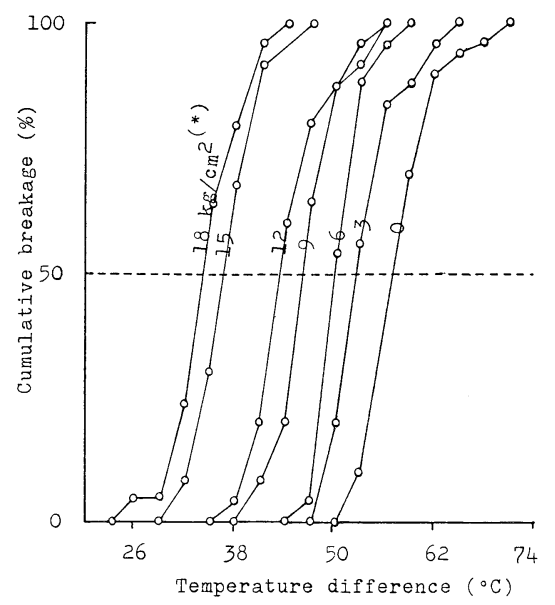

Fig. 3. Effect of internal pressure on the thermal shock breakage.

* Internal pressure

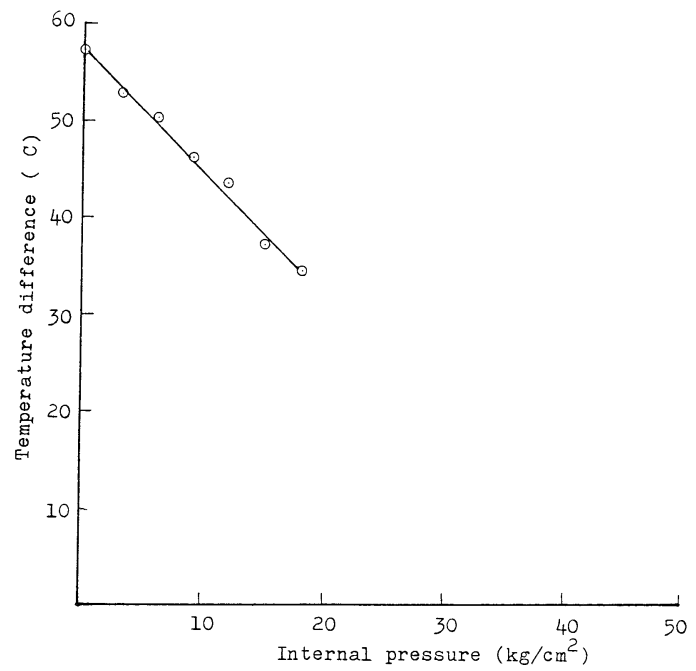

Fig. 4. Plot showing the relation between internal pressure and temperature difference at the bottle breakage.

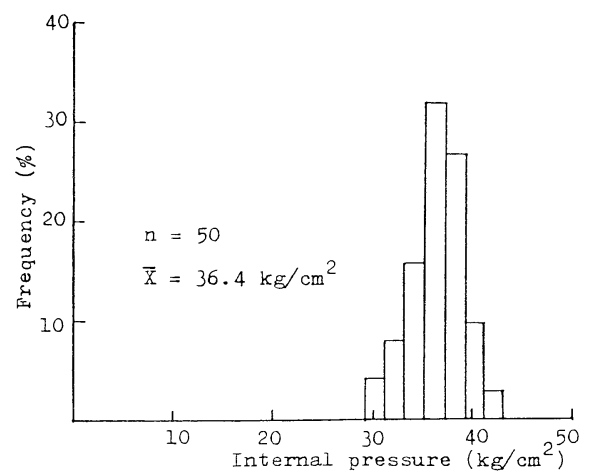

Fig. 5. Internal pressure strength of test bottles. $n$ : Total number of test bottles

\section{4. 理論解析}

\section{1 急冷時にガラス中に発生する温度分布}

いま試料びんの円筒部の外表面に深さ $a$ のララック が発生している場合を考える。この円筒部を初め温度 $T_{\mathrm{i}}$ の温水中に浸漬し, びんの温度が一様に $T_{\mathrm{i}}$ になった 時点で温度 $T_{0}$ の冷水中 $\left(T_{\mathrm{i}}>T_{0}\right)$ に浸漬して, 円筒外 表面に急冷による熱衝撃を与える.

この場合急冷を開始して $t \mathrm{~s}$ 経過後にガラス層に発生 する温度分布は以下の上うな式で示される(4) 17).

$$
f(r, t)=\left(T_{\mathrm{i}}-T_{0}\right) \sqrt{\frac{r}{R_{0}}} \cdot\left[1-\operatorname{erf}\left(\frac{R_{0}-r}{2 \sqrt{k \cdot t}}\right)\right]
$$

ここで erf：ガウスの誤差関数, $r$ : びん円筒部の中心 軸との距離 $(\mathrm{mm}), k$ : ガラスの熱拡散率 ${ }^{20 !}(=0.45$ $\left.\mathrm{mm}^{2} \cdot \mathrm{s}^{-1}\right), t$ : 急冷後の経過時間 $(\mathrm{s}), R_{0}$ : びん円筒部 の外半径 $(=28.5 \mathrm{~mm})$ である.

そこで（1）式について急冷後の経過時間 $0.01 \leqq t \leqq$ $10 \mathrm{~s}$ の範囲にわたり, $f(r, t) /\left(T_{\mathrm{i}}-T_{0}\right)$ の值を求めると, 図6に示すような結果が得られた。

\section{2 急冷による熱衝撃によりガラス中に発生する非 定常熱応力分布}

急冷による熱衝撃によりガラス層に発生する熱応力に ついて考えてみる。まず熱衝撃による試料びんの破壊パ ターンをみると, 破壊起点は表面傷が集中的に発生して いる加傷領域に集中しており，クラックの伸長方向はほ とんどの場合が垂直方向 (軸方向) に向かっていること， また内圧力による破壊パターンについても同様であるこ とから,本研究においてはびん円筒部の円周方向(クラッ クの伸長方向之は直角方向）に発生する熱応力に限定し て検討することにした。

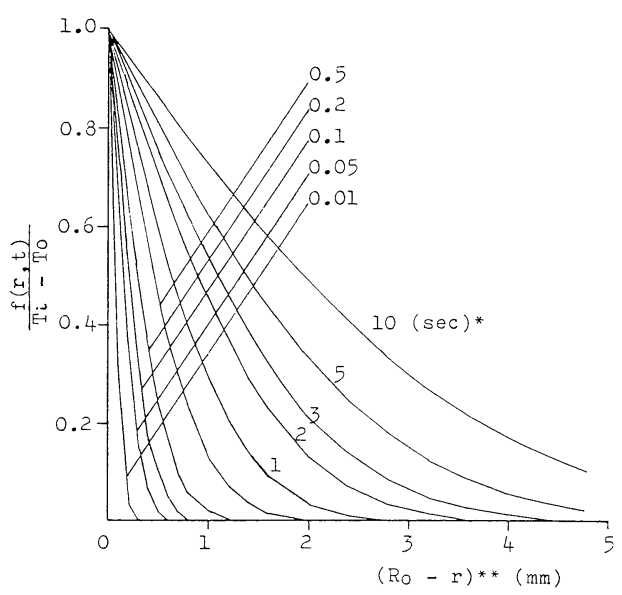

Fig. 6. Temperature distributions, in a sidewall of a glass cylinder induced by cooling at the outer surface (wall thickness : $5 \mathrm{~mm}$ ).

* Elapsed time after the beginning of cooling.

** $\left(R_{0}-r\right)$ : Depth from an outer surface $(\mathrm{mm})$ 


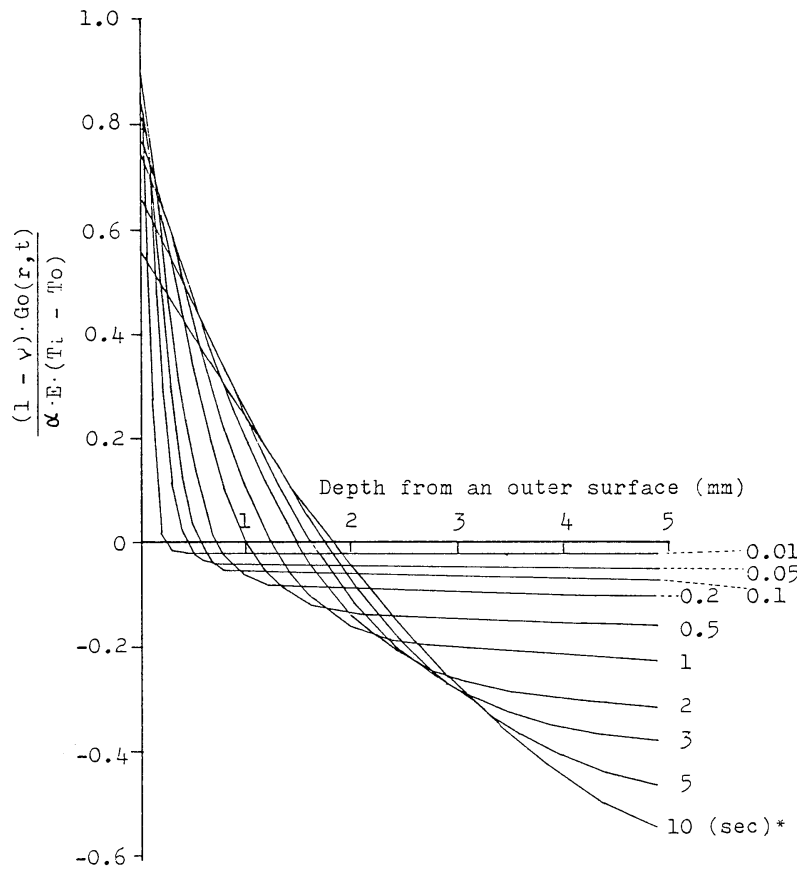

Fig. 7. Thermal stress distributions in a sidewall of a glass cylinder induced by cooling at the outer surface (wall thickness : $5 \mathrm{~mm}$ ).

* Elapsed time after the beginning of cooling

そこで急冷後， $t(\mathrm{~s})$ 経過した時点でのガラス層の 円周方向に発生する熱応力は以下のような関数で示され $3^{81,91}$.

$$
\begin{aligned}
G_{0}(r, t)= & \frac{\alpha \cdot E}{1-\nu} \cdot \frac{1}{r^{2}} \cdot\left[\frac{r^{2}+R_{0}^{2}}{R_{0}^{2}-R_{\mathrm{i}}^{2}} \int_{R_{0}}^{R_{i}} f(r, t) \cdot r \cdot \mathrm{d} r\right. \\
& +\int_{R_{0}}^{T} f(r, t) \cdot r \cdot \mathrm{d} r \\
& \left.+f(r, t) \cdot r^{2}\right]
\end{aligned}
$$

ここで $\alpha$ : 線膨張係数 $\left(=9.5 \times 10^{-6} \cdot{ }^{\circ} \mathrm{C}^{-1}\right), E$ : ヤン グ率 $\left(=6.9 \times 10^{4} \mathrm{MN} \cdot \mathrm{m}^{-2}\right), \nu$ : ポアソン比 ${ }^{201}(=0.25)$, $R_{\mathrm{i}}$ : びん円筒部の内半径 $(=23.5 \mathrm{~mm})$ である. なお $\alpha$ 値は実測值である.

そこで（2）式を基礎として急冷後の経過時間 0.01 $\leqq t \leqq 10 \mathrm{~s}$ の範囲にわたり，無次元化した形での $(1-\nu) \cdot G_{0}(r, t) / \alpha \cdot E\left(T_{\mathrm{i}}-T_{0}\right)$ の值を計算すると図 7 に 示すような結果が得られた。

\section{3 応力拡大係数の時間経過}

非定常熱応力によりガラス円筒部に発生する破壊現象 を検討するため，線形破壊力学によるモードIの応力拡 大係数 $K_{\mathrm{I}}$ の時間変化について, Bueckner ${ }^{211}$ の Weight Function を用いて検討を行った.

まずびん外表面が急冷されてから $t(\mathrm{~s})$ 経過後に, 表面傷の深さが $a$ となったとし, そのときの応力拡大 係数を $K_{\mathrm{I}}(a, t)$ とすれば次式が成立する ${ }^{141,181}$.

$$
\begin{aligned}
K_{\mathrm{I}}(a, t)= & \sqrt{\frac{2}{\pi}} \cdot \int_{R_{0}}^{\left(R_{0}-a\right)} M(a, t) \\
& \cdot G_{0}(r, t) \cdot \mathrm{d} r
\end{aligned}
$$

ここで $M(a, t)$ は以下のように示される.

$$
\begin{aligned}
M(a, t)= & \frac{1}{\sqrt{a-\left(R_{0}-r\right)}} \\
& \cdot\left[1+m_{1}\left\{\frac{a-\left(R_{0}-r\right)}{a}\right\}\right. \\
& \left.+m_{2}\left\{\frac{a-\left(R_{0}-r\right)}{a}\right\}^{2}\right]
\end{aligned}
$$

ここで

$$
\begin{aligned}
& m_{1}=0.6147+17.1844\left(\frac{a}{D}\right)^{2}+8.7822\left(\frac{a}{D}\right)^{6} \\
& m_{2}=0.2502+3.2889\left(\frac{a}{D}\right)^{2}+70.0444\left(\frac{a}{D}\right)^{6}
\end{aligned}
$$

ここで $D$ : 破壊起点が集中する位置（円筒部） の肉厚 $(\doteqdot 5 \mathrm{~mm})$ である.

そこで $(3)$ 式について急冷後の経過時間 $0.01 \leqq t \leqq 10 \mathrm{~s}$ 範囲にわたり無次元化した形 での $\frac{(1-\nu) \cdot K_{\mathrm{I}}}{\alpha \cdot E\left(T_{\mathrm{i}}-T_{0}\right)}$ の值を計算すると, 図 8 に 示すような結果が得られた。

\section{4 表面傷の形状と応力拡大係数の関係}

いま表面傷の形状として以下の 3 種類（A，

$\mathrm{B}$ 及び C夕イプ) を考えてみることにする（図 9 及び図 10 参照).

まずA夕イプはびん外表面に垂直に一様深さ $c_{1}$ のク ラックがびん円筒部の軸方向に連続的に存在していると 仮定した場合である。いまびん円筒部の円周方向に熱応

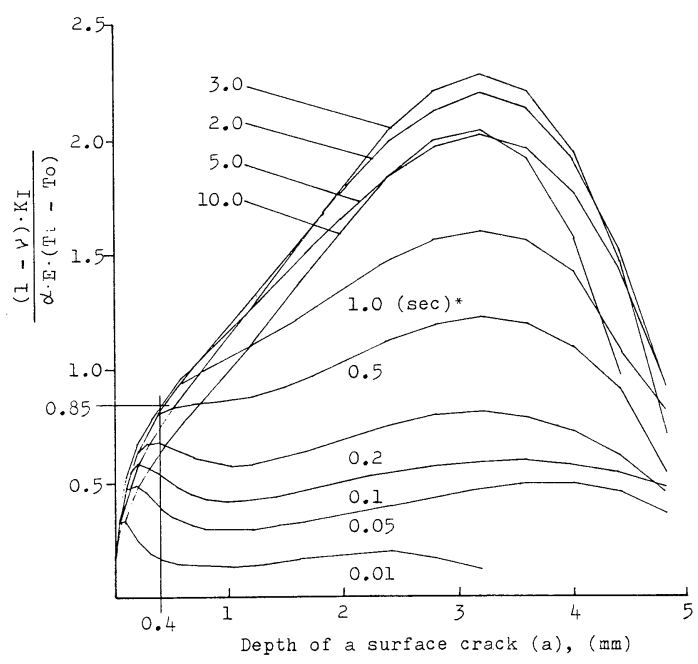

Fig. 8. Distributions of normalized thermal stress intensity factors $\left(K_{\mathrm{I}}\right)$ for continuous axial cracks of depth $(a)$ at the outer surface of a glass cylinder subjected to cooling (wall thickness : $5 \mathrm{~mm}$ ).

* Elapsed time after the beginning of cooling 


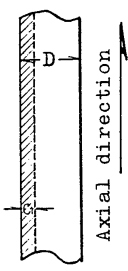

Type-A

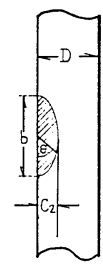

Type-B
Fig. 9. Schematic illustration of surface crack types (A) and (B).

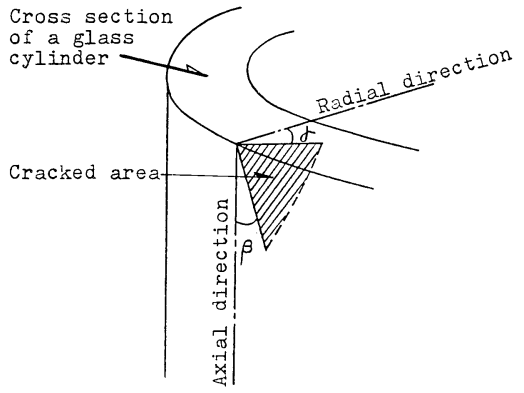

Fig. 10. Schematic illustration of surface crack type (C).

力 $\sigma_{1}$ 及び内圧力による引つ張り応力 $\sigma_{\mathrm{p}}$ が発生している とし， $\sigma_{1}$ と $\sigma_{\mathrm{p}}$ の重量を考えると応力拡大係数は次式で 表される ${ }^{22)}$.

$$
K_{\mathrm{I}}=Y \cdot\left(\sigma_{1}+\sigma_{\mathfrak{p}}\right) \sqrt{\pi \cdot c_{1}}
$$

ここで $Y$ は軸方向に連続的に発生しているクラックに 関する形状係数である。

次にBタイプはびん円筒部の軸方向に半だ円状 (Semi-ellipticall crack) に存在していると仮定した場 合である．この場合半だ円状クラック (深さ $c_{2}$ ) に引つ 張り応力 $\sigma$ が作用するときの応力拡大係数 $K_{\mathrm{I}}$ は以下の 式で表される23!.

$$
K_{\mathrm{I}}=M \cdot \sigma \frac{\sqrt{\pi \cdot c_{2}}}{\Phi}
$$

ただし（6）式はクラック短軸端に対する $K_{\mathrm{I}}$ である. ここで $M$ : クラックに関する形状係数， $\Phi:$ 第 2 種完 全だ円積分であり, 以下のように表される ${ }^{231}$ (図 9 参照).

$$
\Phi=\int_{0}^{\pi / 2}\left[1-\left\{1-\left(\frac{c_{2}}{b}\right)^{2}\right\} \sin ^{2} \theta\right]^{\frac{1}{2}} \cdot \mathrm{d} \theta
$$

ところで実際に試料びんに発生しているクラック (C タイプ）は半だ円状であるが，その伸長方向は様々であ るため（6) 式で $K_{\mathrm{I}}$ を単純に評価することはできない. そこで熱応力 $\sigma_{2}$ と内压力による引っ張り応力 $\sigma_{\mathrm{p}}$ の重量 を考え，更に補正係数 $F(\beta, \gamma)$ を（6）式に導入するこ とにより，Cタイプに関する応力拡大係数 $K_{\mathrm{I}}$ を以下の ように表示し得るものと考えた.

$$
K_{\mathrm{I}}=M \cdot\left(\sigma_{2}+\sigma_{\mathrm{p}}\right) \frac{\sqrt{\pi \cdot c_{2}}}{\Phi} \cdot F(\beta, \gamma)
$$

ここで $F(\beta, \gamma)$ は図 10 に示すように, クラックの伸長 方向がガラス円筒の軸方向と $\beta$ の角度をとりかつ半径 方向と $\gamma$ の角度にあるとした場合の補正係数である.

$\Phi$ は $c_{2} / b$ の值（図 9 参照）によって変化するが, 試料 びん外表面の場合 $c_{2} / b$ は㬰体顕微鏡観察により0.2 0.3 程度に分布していることが分っており，それに対応 する $\Phi$ 值は $\mathrm{Bansal}^{23)}$ によれば1.1〜1.2 程度である.

ところで限界応力拡大係数 $K_{\mathrm{IC}}$ は Mecholsky ${ }^{24)} ら に$ よって得られたソーダ石灰ガラスに関する限界破壊エネ ルギ一値 $\gamma_{\mathrm{c}}\left(=3.5 \mathrm{~J} \cdot \mathrm{m}^{-2}\right)$ を用いて計算し, $K_{\mathrm{IC}} \doteqdot 2.4$ $\mathrm{kg} \cdot \mathrm{mm}^{-\frac{3}{2}}$ を用いることにした。

\section{5. 実験と理論の比較考察}

\section{1 大気压下（内圧ゼロ）での熱衝撃破壊の検討}

図 4 における内圧力と熱衝撃值 (温度差) の直線関係 を中心に以下のような検討を行った．まず大気圧下での 累積破損率 $50 \%$ における試料びんの耐熱衝撃強度（温 度差) を見積もってみると, 図 4 から明らかなように $57^{\circ} \mathrm{C}$ とる。したがってこの值は試料びんにCタイプ のクラックが存在するときの耐熱衝撃強度 $\Delta T_{\mathrm{c}}\left(=T_{\mathrm{i}}\right.$ $\left.-T_{0}\right)$ に対応すると考えてよく, 実験的に $\Delta T_{\mathrm{C}}=57^{\circ} \mathrm{C}$ であるといえる。

ところでこの試料びん群について熱衝撃による破壊起 点が集中するびん底より高さ約 $15 \mathrm{~mm}$ (図 1 参照) で の表面傷の最大深さを実体顕微鏡により測定してみる と, 一律に約 $0.4 \mathrm{~mm}$ 程度であり試料間のばらつきはか なり小さいことが分った (図 11 参照).

次に表面傷がびん外表面に垂直に一様の深さ $(0.4$ $\mathrm{mm}$ ) で軸方向に連続して存在している場合 ( A タイプ) について, 大気圧下での耐熱衝撃強度 $\Delta T_{\mathrm{A}}\left(=T_{\mathrm{i}}-T_{0}\right)$ を理論的に計算してみる. まず表面傷深さ $0.4 \mathrm{~mm}$ に対

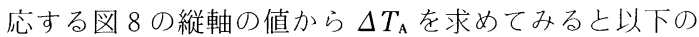

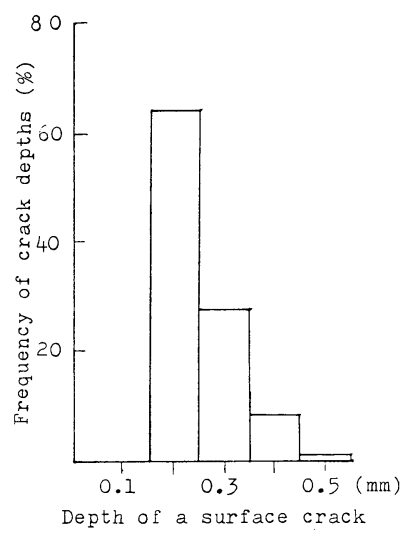

Fig. 11. Distribution of surface crack depths at cylinder sidewalls of test bottles.

Surface cracks shallower than $0.2 \mathrm{~mm}$ is neglected $(n=$ $10)$. 
ようになる。

$$
\frac{(1-\nu) \cdot K_{\mathrm{IC}}}{\alpha \cdot E \cdot\left(T_{\mathrm{i}}-T_{0}\right)}=0.85
$$

ここで $\nu=0.25, \alpha=9.5 \times 10^{-6} \cdot{ }^{\circ} \mathrm{C}^{-1}, \quad E=6.9 \times 10^{4}$ $\mathrm{MN} \cdot \mathrm{m}^{-2}, K_{\mathrm{IC}}=2.4 \mathrm{~kg} \cdot \mathrm{mm}^{-\frac{3}{2}}$ である.

以上の検討結果から大気圧下 (内圧力，ゼロ）での耐 熱衝撃強度は表面傷が A タイプの場合では理論的に $\Delta T_{\mathrm{A}}$ $=31.9^{\circ} \mathrm{C}$ が, また表面傷が C夕イプと仮定される試料 びんに対する実験結果からは $\Delta T_{\mathrm{C}}=57.0^{\circ} \mathrm{C}$ が得られ た.この熱衝撃值の差異は両者の表面傷の形状, 伸長方 向等の違いに対応すると考えてよい.したがって両者の 耐熱衝撃強度（温度差）の比は以下のようになる。

$$
\frac{\Delta T_{\mathrm{C}}}{\Delta T_{\mathrm{A}}} \doteqdot 1.79
$$

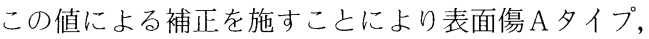
Cタイプ間の耐熱衝撃強度の対応関係を定量的に把握し 得ると考えられる.

また（11）式の值は（5）式及び（８）式から大気圧 下での熱衝擊破壊時の熱応力の比 $\sigma_{2} / \sigma_{1}$ に対応すると考 えてよく，したがって以下の関係が成立すると考えられ る.

$$
\begin{aligned}
\frac{\sigma_{2}}{\sigma_{1}} & =\frac{\Phi}{F(\beta, \gamma)} \cdot \frac{Y}{M} \\
& =1.79
\end{aligned}
$$

ところでクラックに関する形状係数の比 $Y / M$ は円筒 肉厚 $D$ とクラック深さ $c$ の関数で表される. また $Y$ は 以下の式で表される26!.

$$
\begin{gathered}
Y \doteqdot 1.12-0.231\left(\frac{C_{1}}{D}\right)+10.55\left(\frac{C_{1}}{D}\right)^{2} \\
-21.72\left(\frac{C_{1}}{D}\right)^{3}+30.39\left(\frac{C_{1}}{D}\right)^{4}
\end{gathered}
$$

また $M$ の值は ASME の Boiler and Pressure Vessel Code, Section XI の Appendix A ${ }^{271,28)}$ のデー夕を引用 し, 試料びんの肉厚 $5 \mathrm{~mm}$, クラック深さ $0.4 \mathrm{~mm}$ にお ける $Y / M$ を計算すると約 1.05 という值が得られた。 $\Phi \doteqdot 1.1 \sim 1.2$ 及び $Y / M \doteqdot 1.05$ という值を(11) 式に 代入して $F(\beta, \gamma)$ の值を求めると, $F(\beta, \gamma) \doteqdot 0.65$ 0.70 程度の值が得られた.

\section{2 内圧力負荷下での熱衝撃破壊の検討}

図 4 においてびん破壊時の急冷による熱衝撃値と内圧 力による静的応力の間には負の直線関係のあることが実 験結果として得られたが, この直線関係を破壊力学の立 場から理論的に導き出すべく以下のような検討を行っ た。

まず表面傷がAタイプのびんを想定し，あらかじめ所 定の内压力を負荷してびん外表面を急冷した場合につい て検討してみる. 熱応力を $G_{0}(r, t)$, 内圧力による静的 な応力を $G(r, p)$ とすれば, 総応力 $G(r, t)$ は以下のよ
うに示される.

$$
G(r, t)=G_{0}(r, t)+G(r, p)
$$

ここで $G_{0}(r, t)=\frac{\alpha \cdot E}{1-\nu} \cdot G_{1}(r, t), G(r, p)=\frac{\alpha \cdot E}{1-\nu} \cdot F$ と おいて，式を無次元化すれば以下のようになる.

$$
\frac{1-\nu}{\alpha \cdot E} \cdot G(r, t)=G_{1}(r, t)+F
$$

ここで $F$ はガラス円筒を急冷した場合に外表面に発生 する最大熱応力を 1 とした場合の比として無次元化した ものである.

ところで本研究においては $F$ の値として $0.05 ， 0.1$, 0.2 及び 0.3 の 4 水準をとった. なおこの $F$ 值の範囲 は本実験で試料びんに負荷した最高内圧力が $18 \mathrm{~kg} \cdot \mathrm{cm}^{-2}$ (図 3 参照) であったところから，その值にほぼ対応す る值として $F$ 值は最高 0.3 までとした。

次にこれら内圧力負荷条件でびんに熱応力を与えた場 合の応力拡大係数 $K_{\mathrm{I}}$ の時間的経過を Bueckner ${ }^{211}$ の Weight function を用いて計算を行い，その結果を図 12 に例示する. 図 12 のグラフ群において表面傷深さ 0.4 $\mathrm{mm}$ に対応するびん破壊時の破壊応力を熱衝撃值（温度 差 $\left.\Delta T_{\mathrm{A}}\right)$ として, グラフの縦軸から読み取って (9) 式のような計算を行い, $\Delta T_{\text {A }}$ を求めてその結果を表 2 に示す. 次に $(10)$ 式の対応関係から $\Delta T_{\mathrm{C}}$ が算出し得て, その結果を同じく表 2 に示す.

ところで $\Delta T_{\mathrm{c}}$ として表されたびんが破壊したときの 温度差は非定常熱応力としての熱衝撃値 $\left(\Delta T_{\mathrm{t}}\right)$ と内圧 力 $P$ の負荷による定常応力に対応した熱衝撃值 $\left(\Delta T_{\mathrm{p}}\right)$ の和と考えてよいから以下のように示される.

$$
\Delta T_{\mathrm{c}}=\Delta T_{\mathrm{t}}+\Delta T_{\mathrm{p}}
$$

ここで（15）式より以下の関係が導かれる.

$$
\Delta T_{\mathrm{t}}=\frac{1}{1+F} \cdot \Delta T_{\mathrm{c}}, \Delta T_{\mathrm{p}}=\frac{F}{1+F} \cdot \Delta T_{\mathrm{c}}
$$

(16) 式より $F$ のそれぞれの值に対する $\Delta T_{\mathrm{t}}$ 及び $\Delta T_{\mathrm{p}}$ を求めて表 2 に示す.

ところで $\Delta T_{\mathrm{p}}$ によりびん外表面の円周方向に発生す る応力 $\sigma_{\mathrm{p}}$ は以下の上うに示される.

$$
\sigma_{\mathrm{p}}=\frac{\alpha \cdot E}{1-\nu} \cdot \Delta T_{\mathrm{P}}
$$

一方内圧力 $P$ を負荷した場合にびん外表面の円周方 向に発生する応力 $\sigma_{\mathrm{p}}$ は以下の上うに示される29!.

Table 2. Calculations of temperature difference/internal pressure relations at a bottle breakage for various $F$-values.

\begin{tabular}{|l|c|c|c|c|c|}
\hline F-Value & $\begin{array}{c}\Delta \mathrm{T}_{\mathrm{A}} \\
\left({ }^{\circ} \mathrm{C}\right)\end{array}$ & $\begin{array}{l}\Delta \mathrm{T}_{\mathrm{C}} \\
\left({ }^{\circ} \mathrm{C}\right)\end{array}$ & $\begin{array}{l}\Delta \mathrm{T}_{\mathrm{t}} \\
\left({ }^{\circ} \mathrm{C}\right)\end{array}$ & $\begin{array}{l}\Delta \mathrm{T}_{\mathrm{p}} \\
\left({ }^{\circ} \mathrm{C}\right)\end{array}$ & $\begin{array}{c}\mathrm{P} \\
\left(\mathrm{kg} / \mathrm{cm}^{2}\right)\end{array}$ \\
\hline 0 & 31.9 & 57.0 & 57.0 & 0 & 0 \\
0.05 & 29.6 & 52.8 & 50.3 & 2.5 & 6.1 \\
0.10 & 27.6 & 49.3 & 44.8 & 4.5 & 10.9 \\
0.20 & 24.3 & 43.4 & 36.1 & 7.2 & 17.6 \\
0.30 & 21.7 & 38.7 & 29.8 & 8.9 & 21.8 \\
\hline
\end{tabular}




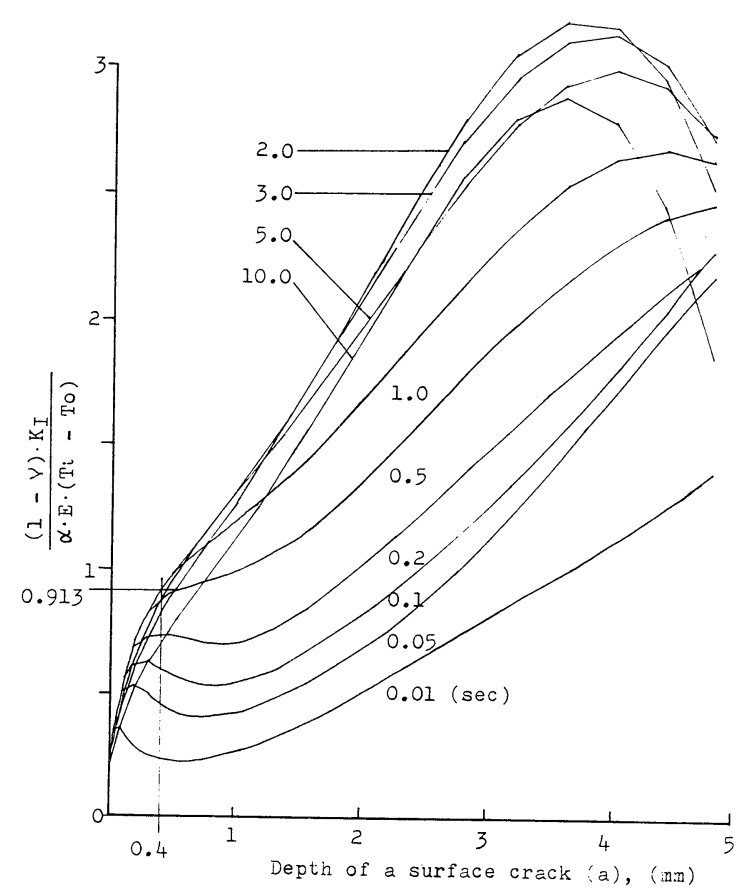

(1) $F=0.05$

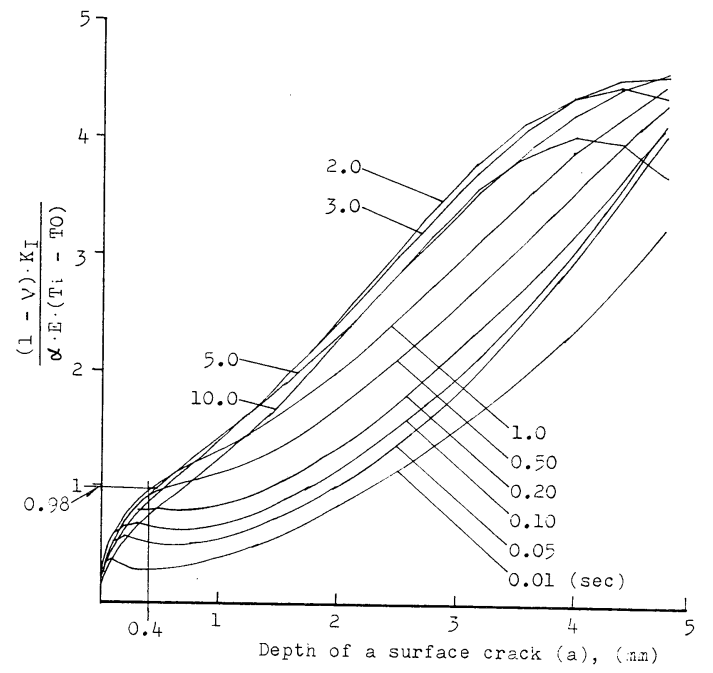

(2) $F=0.1$

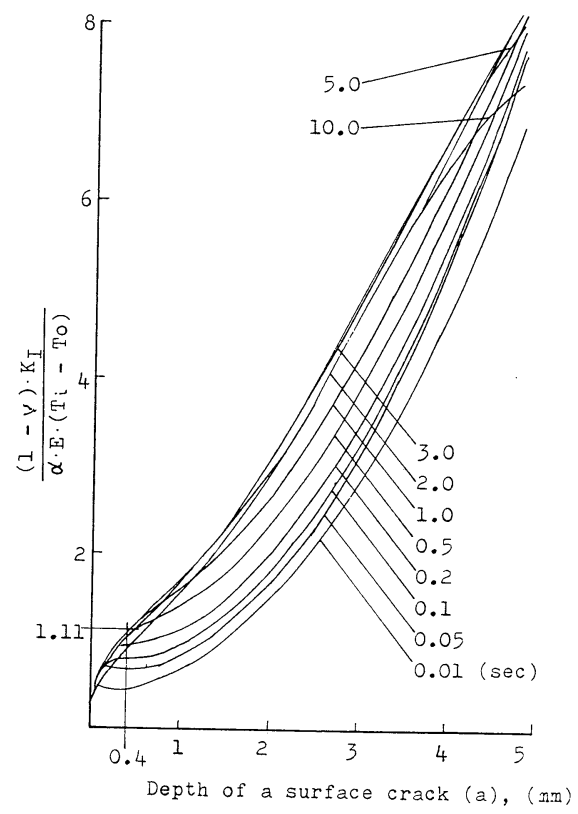

(3) $F=0.2$

Fig. 12. Normalized thermal stress intensity factor $\left(K_{\mathrm{I}}\right)$ as a function of crack depth with elapsed time as a parameter.

$$
\sigma_{\mathrm{p}}=\frac{2 R_{\mathrm{i}}^{2}}{R_{0}^{2}-R_{\mathrm{i}}^{2}}
$$

（17）式及び（18）式から $\Delta T_{\mathrm{p}}$ と $P$ の関係が求まり, $\Delta T_{\mathrm{p}}$ に対応する $P$ を計算して表 2 に示す.

以上の理論計算から得られた $\Delta T_{\mathrm{t}}$ と $P$ の関係をプ
ロットして図13 (グラフの・印 (calculated values) に対応）に示す。図 13 から明らかなように理論値は実 測値とかなりよい一致が認められた。

\section{3 内圧力の負荷時間と破壊強度の関係}

耐熱圧強度試験においてびん外表面が冷却されてから 


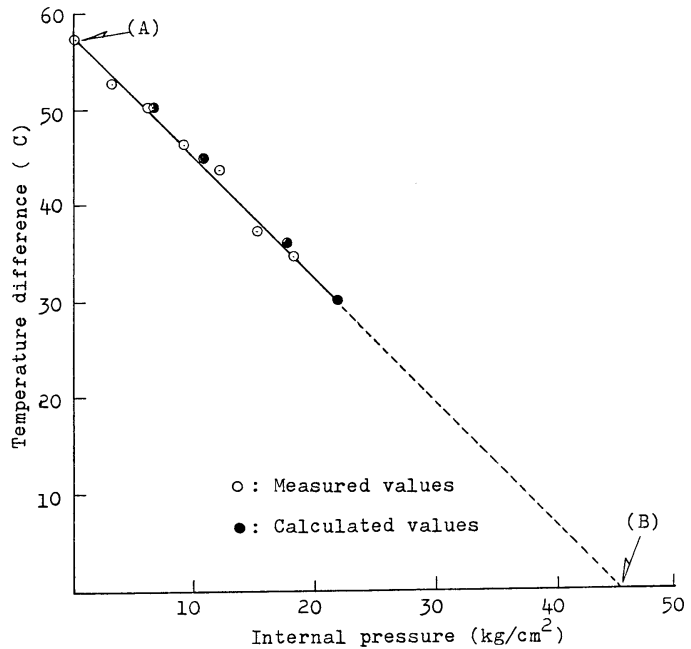

Fig. 13. Plot showing the relation between internal pressure and temperature difference at the bottle breakage.

Broken line : Line of extrapolation

破壊するまでに要した時間は 1 ～秒間程度の瞬間的な ものであり，本実験における試料びんの瞬間耐内圧力強 度（所定の内圧力を負荷して $1 \sim 3$ 秒間経過後に破壊に 至る強度と業界では定義されており，実用的な強度基準 とされている ${ }^{91-121}$ ) は図 13 のB点に対応しており, $46.0 \mathrm{~kg} \cdot \mathrm{cm}^{-2}$ が推定值として得られた.

なお試料びんの 1 分間持続耐内圧力強度は実測值とし て $36.4 \mathrm{~kg} \cdot \mathrm{cm}^{-2}$ が得られており, 両者の比として $36.4 / 46.0 \div 0.79$ なる值が得られた。この比については Borchard $^{25)}$ によれば 0.77 を報告しており, Sigwart ${ }^{111}$, Schönbrunn"121 によれば 0.79 を報告している.したがつ て本実験の結果はこれらの值にほぼ一致していることが 分る.

\section{6. 結 語}

リターナブル（回収，再使用可能）のガラスびんを対 象として，びんに所定の内圧力を負荷した状態下で，び ん外表面に急冷による熱衝撃を与えた場合の強度特性に ついて検討を行い, びん破壊時の内圧力と熱衝撃値（急 冷による温度差を尺度とする）の間には直線関係のある
ことが分った.

またびん外表面に発生したクラック形状の差異とびん 強度の関係について, 表面傷が一様深さで連続的に発生 している場合 (Straight-front crack) と半だ円状の場合, (Semi-elliptical crack) を比較すると, クラック深さ が同じであれば, 両者の破壊強度の比はクラック形状係 数の比と対応関係にあることが分った。

\section{文献}

1) J. B. Murgotroyd, J. Soc. Glass Technol., 26, 22-34 (1942).

2) J. B. Murgatroyd, J. Soc. Glass Technol., 28, 77-93 (1944).

3) W. D. Kingery, J. Am. Ceram. Soc., 38, 1-15 (1955).

4) D. Bussing, Glastechn. Ber., 37, 100-02 (1964).

5) S. Yokokura, Rept. Res. Lab. Kirin Brewery Co., Ltd., 25, 57-62 (1983).

6) 横倉修一, 白倉 昌, 材料科学, 19, 323-29 (1983).

7）横倉修一，窯協，91，429-36（1983）.

8) S. Yokokura, Proceedings of the 17th Congress of European Brewery Convention, 237-43 (1979).

9) Deutsche Normen, DIN 52320 (1957).

10) L. H. Lehnert, Glastechn. Ber., 28, 259-64 (1955).

11) H. Sigwart, Glastechn. Ber., 25, 276-85 (1952).

12) G. Schönbrunn, Glastechn. Ber., 38, 329-33 (1965).

13）横倉修一, 吉田明輝, 窯協, 91, 196-98 (1983).

14) D. Stahn, Glastechn. Ber., 50, 206-13 (1977).

15) A. F. Emery, J. Basic Engineering, 45, 45-52 (1966).

16) H.S. Carslaw and J. C. Jager, "Conduction of Heat in Solids", Oxford Univ. Press (1980) p. 327-37, 489.

17) A. F. Emery, G. E. Walker and J. A. Williams, J. Basic Engineering, 48, 618-22 (1969).

18) D. Stahn and F. Kerkhof, Glastechn. Ber., 50, 121-28 (1977).

19) G. Blauel, J. K. Kalthoff and D. Stahn, J. Eng. Material and Technalogy, 299-303 (1974).

20) R. Badallance, D. A. Krohn and D. P. H. Hasselman, J. Am. Ceram. Soc., 57, 432-36 (1974).

21) G. C. Sih, "Mechanics of Fracture, Vol. 1", Noordhoff International Pub., Leyden (1973) p. 306.

22）岡村弘之, “線形破壊力学入門”, 培風館 (1976) p. 119.

23) G. K. Bansal, J. Am. Ceram. Soc., 59, 87-88 (1976).

24) J. J. Mecholsky, R. W. Rice and S. W. Freiman, J. Am. Ceram. Soc., 57, 440-43 (1974).

25) K. H. Borchard, VDI-Zeitschrift, 1461-63 (1938).

26) 岡村弘之, “線形破壊力学入門”, 培風館 (1976) p. 217.

27) Appendix A. Evaluation of Flaw Indications, to ASME Boiler and Pressure Vessel Code Section XI, Rules for inservice inspection of nuclear reactor coolant systems (1974).

28）金沢 武, 越賀房夫, “脆性破壊 2”, 培風館 (1981) p. 101.

29）例えば，野原石松，“圧力容器”, 共立出版 (1972) p. 12223. 